\title{
EFFECTS OF THE APPLICATION OF TRICHINELLOSIS CONTROL PROGRAM IN AN ENDEMIC AREA IN SERBIA
}

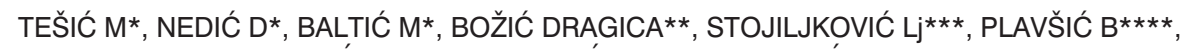
TAJDIĆ NADA*, MIRILOVIĆ $M^{*}$ and RAJKOVIĆ $M^{* * * * *}$

\footnotetext{
*University of Belgrade, Faculty of Veterinary Medicine, Srbija; **University of Belgrade, Faculty of

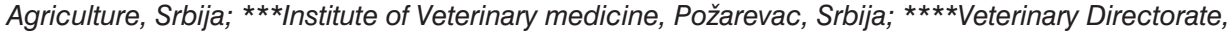
Ministry of Agriculture, Beograd, Srbija; ${ }^{* \star * * * I n s t i t u t e ~ o f ~ V e t e r i n a r y ~ m e d i c i n e, ~ K r a l j e v o, ~ S r b i j a ~}$
}

\section{(Received $1^{\text {st }}$ September 2010)}

Trichinellosis is a disease that affects both humans and animals, caused by a parasite from the Trichinellidae family and Trichinella genus. Humans get infected by consuming infected and inadequately thermally treated meat from domestic or wild animals containing cocooned infective larvae of $T$. spiralis. Aside from health problems caused by trichinellosis as a zoonosis, there is no doubt that it represents a serious economic problem for swine meat producers. The research in this paper has been performed in Serbia, in a region which is located at the confluence of two large rivers, and it is the geographical location which makes it an endemic area for the presence of T. spiralis. Epidemiological data pertains to the period of 1995-2003, but also to the period 2003-2009, when the implementation of the program for control and eradication of trichinellosis was complete. The diagnostic testing of cadavers of slaughtered swine for the presence of T. spiralis in the period of 1995-2003 included $41.04 \%$ of the slaughtered swine, out of which $0.4281 \%$ were positive, and the amount of economic loss was 95301000 dinars or about one million EUR. The infection was confirmed in 432 patients during the research period. The preparation of the program for the control and eradication of trichinellosis has been made in accordance with applicable laws and technological standards, with a clear determination of input and output using a cost-benefit analysis. The effects of its application show a reduction in the number of swine which are positive for the presence of $T$. spiralis by a factor of three times $(p<0.01)$, and the present net value $(P N V)$ and the benefit/cost ratio $(B / C)$ show economic and epidemiological justification.

Key words: control program, economics, epidemiology, trichinellosis 


\section{INTRODUCTION}

Trichinellosis is a disease that affects both humans and animals, caused by a parasite from the Trichinellidae family and Trichinella genus. So far this parasitic infection was discovered in over a hundred species of mammals on all continents (Murrell et al., 1987; Scripova et al., 1994; Boireau et al., 2002), and the most common among them in our country is Trichinella spiralis (Đorđević, 1989; Teodorović et al., 1999). It is highly infectious and pathogenic for humans, the reservoir for this species are pigs and rats (Knappen, 1987; Pozio, 1998), and the most significant source of infection for humans is the meat and certain products from domestic pigs and wild boars (Čuperlović et al., 1989).

The clinical symptoms of the disease in animals, primarily pigs, are very hard to notice and diagnose during their lifetime, while it is fairly easy and simple to diagnose the presence of infective larvae with a postmortal examination (Zimmerman, 1983; Kotula, 1983; Murrell, 1983; Bell, 1984; Đorđević, 1991; Teodorović et al., 1999). Humans are usually infected in cases when they consume infective meat, and after the infection and incubation period which varies from six to fifteen days, appear pronounced clinical symptoms (Chodera, 1974; Pawlowski, 1983; Ramisz, 1989; Phaheuf et al., 1984).

Trichinellosis has been present in the observed region for many years now, and the incidence of swine infection and number of infected humans has lead to the fact that in 2003 local authorities have declared an infected area on the territory of six municipalities. The local authorities have launched partial rat extermination, and this veterinary-sanitarian measure resulted in a decreased number of infected pigs in all municipalities by $20.73 \%$ and a decreased number of inhabited places by $36.81 \%$. However, even with these positive results, the percentage of infected pigs is still high in the last two years $(2002-0.66 \%$ and $2003-0.62 \%)$ and the competent state authorities are issuing a decision on systematic control and repression of trichinellosis in the observed region (Tešić et al., 2002; Stojiljković, 2005).

Aside from health problems caused by trichinellosis as a zoonosis, there is no doubt that that it represents an economic problem (Rushton et al., 1999; Mirilović, 2006). The problem of determining economic losses caused by the presence of infected pigs in our country has not been expressly studied, and the calculation of value of unrealized profit and expected income have not been considered (Đorđević, 1991; Thruisfeld, 1995; Teodorović et al., 1999; Čuperlović et al., 1989; Stojiljković, 2005).

The preparation of the program of control of the disease in the observed region was based on an unfavorable epidemiological state and determined economic losses. The preparation of a consistent program for control and eradication of trichinellosis has been made in accordance with applicable legislation, with a determination of input and output necessary for their preparation, and also the precise amount of expenses and amount of expected income from realized benefits (Chodera, 1974; Carpenter, 1994; Tešić et al., 2004; Stojiljković, 2005). The application of cost-benefit analysis (CBA) has pointed out the justification of the preparation of the program, and its evaluation was 
performed based on present net value - PNV and the ratio of benefit and cost RBC (Knappen and Ring, 1996; Dijkhuizen et al., 1997; Horst et al., 1999; Knappen, 2000; Stojiljković, 2005).

\section{MATERIAL AND METHODS}

To study the outspread of trichinellosis we used samples of swine diaphragms, i.e. cadavers originating from individual slaughters in the private sector, and from slaughterhouses where the slaughter of pigs was being performed according to the regulations of veterinarian-sanitary supervision. The material for diagnosing the presence of $T$. spiralis was gathered on the territory of the observed region. Diagnostic examination of the samples was performed using the compression method and artificial digestion.

The compression method or trichinoscopy was used for examining samples from individual slaughters in the private sector. Trichinoscopy was performed at veterinary stations, or veterinary clinics by an authorized veterinarian. The samples were obtained and brought for examination to the veterinary station or clinic by the owner of the animal. The provided sample, taken from each pillar of the diaphragm, is harvested and 28 pieces of meat is cut out, the size of a wheat grain (weight $0.5 \mathrm{~g}$ ) and placed on the bottom compression glass. If $T$. spiralis is present in the specimen, the parasite can be seen inside a capsule, in the shape of a spiral, number 8 or the letter $\mathrm{S}$. The capsule is in the shape of a lemon, 0.3 to $1.2 \mathrm{~mm}$ long and 0.02 to $0.03 \mathrm{~mm}$ wide.

Artificial digestion was used at slaughterhouses and in laboratories when the obtained sample came from dry-cured or air-dried meat products, or when the test was performed on a collective sample from pigs which were slaughtered during the day in the slaughterhouse. The application of this method included a rapid procedure of artificial digestion, which consisted of the following stages: chopping up samples, artificial digestion, sedimentation and microscope examination. When raw meat was examined in slaughterhouses samples were taken from a hundred pigs, one gram from each pig, and chopped up together. The sample was collected from the diaphragm muscle. The examination searched for $T$. spiralis larvae which can have the shape of a spiral, number eight, or outstretched. If larvae presence in the sample has been confirmed, then the same process was repeated, only for a smaller number of swine cadavers in order to isolate the sample and pig which contained $T$. spiralis larvae.

The retrospective study of the epidemiological state of trichinellosis in the observed region was performed with analyses carried out in municipalities and inhabited places in the period of 1995-2004. For the purposes of the planned research, records from the competent veterinary institute and institute for health protection, as well as veterinary stations and slaughterhouses were taken. The prevalence and incidence of trichinellosis has been calculated using the descriptive statistics method, the significance of the difference between the prevalence and damages has been evaluated using Student's t-test, and the results were presented. The economic damages were quantified with nature and value methods. In the natural method, the total mass of the animals based on the 
coefficient for conditional animals, and the value of economic damages was calculated considering market prices per $\mathrm{kg}$ of live stock animals in the given year. The economic program of control and eradication of trichinellosis in the observed region was done using cost-benefit analysis (CBA). Starting from the theoretical interaction of the causing agent, the host and the environment, along with quantification of input and output in the application of CBA the program was projected for a period of six years. The projected program model was evaluated based on the movement of the prevalence and incidence during its application, as well as based on present net value (PNV) and the benefit/cost ratio $(\mathrm{B} / \mathrm{C})($ Horst et al., 1999; Rusthon et al., 1999; Tešić et al., 2002).

\section{RESULTS}

The average number of pigs tested for T. spiralis during the nine-year period in the observed region was 188.342 pigs, and the percentage of organized slaughter in slaughterhouses is $39.94 \%$, and individual slaughters in the private sector amount to $60.06 \%$ (Table 1). The variability of the number of tested pigs is the largest at individual slaughter $(\mathrm{CV}=48.27)$.

Table 1. The number of pigs tested for the presence of $T$. spiralis

\begin{tabular}{|c|l|c|c|c|c|c|c|}
\hline No. & Territory & $\mathrm{n}$ & $\overline{\mathrm{X}} \pm \mathrm{S} \overline{\mathrm{x}}$ & $\mathrm{SD}$ & $\mathrm{CV}$ & $\mathrm{Xmin}$ & $\mathrm{Xmax}$ \\
\hline \hline 1. & Total & 9 & $188.342 \pm 14.213$ & 42.640 & 22.64 & 135475 & 254555 \\
\hline 2. & Indiv. slaughter & 9 & $112.454 \pm 18.094$ & 54.281 & 48.27 & 46812 & 199659 \\
\hline 3. & Organ. slaughter & 9 & $74.777 \pm 8.018$ & 24.054 & 32.17 & 36111 & 103951 \\
\hline
\end{tabular}

The average number of pigs tested positive for $T$. spiralis was 800.10 pigs, and the percentage of positive pigs in organized slaughter was $10.96 \%$, and in individual slaughter it was $89.04 \%$. The variability of the occurrence of pigs positive for T. spiralis is very high, but also the variability in individual slaughter and organized slaughter is proportionate (Table 2).

Table 2. The number of pigs positive for the presence of $T$. spiralis

\begin{tabular}{|c|l|c|c|c|c|c|r|}
\hline No. & Territory & $\mathrm{n}$ & $\overline{\mathrm{X}} \pm \mathrm{S} \overline{\mathrm{x}}$ & $\mathrm{SD}$ & $\mathrm{CV}$ & $\mathrm{Xmin}$ & $\mathrm{Xmax}$ \\
\hline \hline 1. & Total & 9 & $800.10 \pm 104.00$ & 311.76 & 38.99 & 328 & 1245 \\
\hline 2. & Indiv. slaughter & 9 & $712.20 \pm 105.60$ & 316.70 & 44.47 & 258 & 1100 \\
\hline 3. & Organ. slaughter & 9 & $87.89 \pm 12.97$ & 38.92 & 44.28 & 36 & 145 \\
\hline
\end{tabular}

Prevalence is the percentage of pigs tested positive for the presence of $T$. spiralis compared to the total number of examined slaughtered pigs in sectors of slaughter. In total, during the nine-year period the registered prevalence was $0.4281 \%$, while the highest rate of infection was noted in the year $2000(0.5664 \%)$, and the lowest in the first year $(0.2421 \%)$. In individual slaughter prevalence was 
$0.6346 \%$, and in slaughters in slaughterhouses was $0.1175 \%$. The highest rate of infection in individual slaughter was recorded in 1996 (0.8993\%), and in slaughterhouses it was in the year 2000 (0.1909\%), while the lowest prevalence was registered in 1998 (0.5224\%) and 2003 (0.0650\%) respectively according to sectors.

Economic damages are caused by discarding cadavers of slaughtered pigs in the observed region. Total damages in the observed region are EUR 953012.10 or on average per year EUR 105 890.23. The highest damages occurred in 2001. and in 1999. and the lowest were in the first and second year of the observed period. There is a noticeable growth rate of the economic damages in the observed period of $20.3 \%$.

The total number of people who were infected and hospitalized do to trichinellosis in the observed region from 1995. to 2003. was 432. The highest count was registered in 1995 and 1997, and the lowest was in 2002 and 1998. During the nine-year period, 58.80 percent of the total number of infected people were male, while $41.20 \%$ were female, and the highest number of infected people $(64.13 \%)$ was in the $20-59$ age group.

Starting from the health and economic significance of trichinellosis in the preparation of the program of control an eradication of trichinellosis, a series of measures were taken, determining the dynamics of their implementation, as well as the consumption of material, labor, and cost value were calculated. Starting elements for the projection of the program were certain technological standards and values for serological examination, rat extermination and trichinoscopy. The prices for the services of rat extermination, serological examination and trichinoscopy were based on an applicable pricelist for veterinary services, and market prices were used for prices of the required materials. The total anticipated expenditures for the realization of the program amount to EUR 3352 650, while the percentage of costs for serological diagnostics is $15.58 \%$, rat extermination $19.74 \%$ and trichinoscopy $64.68 \%$. Beside the planned expenditures, there was also a prediction for profit during the implementation of the program. The planned profit based on reducing the rates of infection and numbers of discarded cadavers of slaughtered pigs and reducing costs of trichinoscopy in the observed region during a period of six years amounts to EUR 3871980 , and this amount was reached by reducing the infection of pigs by $30.87 \%$ and saving expenses for trichinoscopic examinations of the cadavers of slaughtered pigs by $69.13 \%$ (Table 3).

The cost-benefit analysis has shown social justification of the program for the control of trichinellosis for the six-year period (Table 4). Since the dynamic method was used, nominal values were discounted using the discount factor, thus determining the present net value of PNV = EUR -99 916.85, while the RBC coefficient was less than 1.

During the implementation of the program, from 2004 to 2009, positive effects of its application have been recorded, and shown in Table 5. New cases of infection in humans have not appeared in the final two years, and the prevalence is significantly smaller than at the initial stages of the program $(p<0.01)$, and so are the economic damages, which were reduced by two thirds. 
Table 3. Structure of the planned profit and expenses

\begin{tabular}{|c|c|c|c|c|c|}
\hline \multirow{2}{*}{ Year } & \multicolumn{2}{|c|}{ Expected profit, \% } & \multicolumn{3}{c|}{ Planned expenses, \% } \\
\cline { 2 - 6 } & $\begin{array}{c}\text { Reduction of } \\
\text { infection }\end{array}$ & $\begin{array}{c}\text { Reduction of } \\
\text { trichinoscopy } \\
\text { costs }\end{array}$ & $\begin{array}{c}\text { Serological } \\
\text { diagnostics }\end{array}$ & $\begin{array}{c}\text { Rat } \\
\text { extermination }\end{array}$ & $\begin{array}{c}\text { Trichinoscopy } \\
\text { costs }\end{array}$ \\
\hline \hline 1. & 4.26 & - & 16.66 & 37.60 & 35.09 \\
\hline 2. & 12.77 & - & 16.67 & 18.80 & 26.32 \\
\hline 3. & 19.19 & 14.62 & 16.66 & 18.80 & 17.55 \\
\hline 4. & 21.26 & 19.58 & 16.67 & 9.12 & 10.51 \\
\hline 5. & 21.26 & 30.65 & 16.67 & 9.12 & 7.02 \\
\hline 6. & 21.26 & 35.15 & 16.67 & 6.56 & 3.51 \\
\hline $\begin{array}{l}\text { EUR } \\
\text { total }\end{array}$ & 1195410 & 2676570 & 522360 & 661650 & 2168640 \\
\hline
\end{tabular}

Table 4. Cost-benefit analysis of the program for the control of trichinellosis

\begin{tabular}{|c|c|c|c|c|c|}
\hline \multirow{2}{*}{ Year } & \multicolumn{2}{|c|}{$\begin{array}{c}\text { Nominal vale, } \\
\text { EUR }\end{array}$} & \multirow{2}{*}{$\begin{array}{c}\text { Discount } \\
\text { factor, 9\% }\end{array}$} & \multicolumn{2}{c|}{$\begin{array}{c}\text { Present value } \\
\text { EUR }\end{array}$} \\
\cline { 2 - 3 } & Benefit & Costs & & Benefit & Costs \\
\hline \hline 1. & 50880 & 1096840 & 0.9174 & 46677.31 & 1006241.02 \\
\hline 2. & 152630 & 782221 & 0.8417 & 128468.67 & 658395.42 \\
\hline 3. & 533360 & 591950 & 0.7721 & 411788.73 & 457044.60 \\
\hline 4. & 804130 & 375470 & 0.7084 & 569645.69 & 265982.95 \\
\hline 5. & 1104500 & 299640 & 0.6499 & 717814.55 & 194736.04 \\
\hline 6. & 1226480 & 206540 & 0.5962 & 731227.38 & 123139.15 \\
\hline Total & 3871980 & 3352650 & - & - & - \\
\hline PV & - & - & & 2605622.33 & 2705539.18 \\
\hline PNV & \multicolumn{2}{|c|}{619330.00} & & \multicolumn{2}{c}{-99916.85} \\
\hline RBC & \multicolumn{2}{|c|}{1.1549} & & & \multicolumn{2}{c}{0.9631} \\
\hline
\end{tabular}

Table 5. Effects of the application of the Program for control of trichinellosis

\begin{tabular}{|l|c|c|c|}
\hline Elements & $\begin{array}{c}\text { Before program } \\
\text { application - in 2003 }\end{array}$ & $\begin{array}{c}\text { After program } \\
\text { application - in 2009 }\end{array}$ & Difference \\
\hline \hline Number of tested pigs & 254555 & 187561 & -66994 \\
\hline Number of positive pigs & 1099 & 144 & -855 \\
\hline Prevalence, \% & 0.4317 & 0.0768 & $-0.3549 \star *$ \\
\hline Economic damages, EUR & 135212 & 28064 & -107148 \\
\hline Number of infected people & 14 & 0 & -14 \\
\hline
\end{tabular}

** $p<0.01$ 


\section{DISCUSSION}

Trichinellosis is a zooparasitosis caused by a parasite from the Trichinellidae family, and in our regions the dominant species is Trichinella spiralis (Murrell et al., 1987; Sanchez-Acedo et al., 1989; Pozio, 1998; Scripova et al., 1994; Boireau et al., 2002). Rodents, specifically rats, are the main host and reservoir for $T$. spiralis. Swine, as the most significant animal species for the transfer of this disease to humans get infected through ingestion of dead or living rats which carry the infective larvae, or when their feedstuff contains inadequately thermally treated confiscates from slaughterhouses originating from infected pigs (Murrell, 1983; Đorđević, 1989; Pozio, 1998; Teodorović et al., 1999). There are no visible clinical symptoms in infected pigs, and it is very difficult to notice them during the lifetime of the animal, while with a portmortal examination it is fairly easy and simple to diagnose the presence of infective larvae in the muscles (Zimmerman, 1983; Kotula, 1983; Bell, 1984; Đorđević, 1991; Teodorović et al., 1999).

The number of pigs tested for the presence of $T$. spiralis shows a certain variability during the observed period, and out of the total number of pigs tested for the presence of $T$. spiralis, $39.94 \%$ have been slaughtered in slaughterhouses where veterinary-sanitarian examination is performed before and after the slaughter, and $60.06 \%$ have been slaughtered individually - in the owner's household yards, for which cases the samples were subjected to trichinoscopy in veterinary stations and clinics. In their research, Đorđević (1989) and Čuperlović et al. (1989) list as endemic areas of trichinellosis these regions: Danube river basin, Drina and Kolubara basin and Srem, concluding that trichinoscopy should be performed on a larger number of pigs from the private sector as opposed to the communal sector where the infection rate in pigs is very low. The average number of pigs positive for $T$. spiralis, was 800.10 of pigs with a constant tendency of growth. The average percentage of infected pigs in the region was $0.4281 \%$, but having in mind that individual slaughters had a percentage of $0.6346 \%$, while in organized slaughter the percentage was $0.1175 \%$. The largest number of pigs infected with $T$. spiralis was recorded in four municipalities, where the percentage of positive animals is by far dominant in individual slaughters. Čuperlović et al. (1989) list a high rate of infection of pigs in rural households of the Kladovo municipality, adding that the infection rate was higher in older categories compared to piglets. Also, Đorđević (1989) in his research confirms a higher rate of infection in pigs in the private sector compared to communal farms where there was no infection. The author notes that the highest rate of infection was recorded in one municipality $(0.5480 \%)$. During and after the economic crisis in Serbia, Tešić et al. (2004) observe the spread of the T. spiralis infection of pigs and indicated a high infection rate (0.5838\%) in the observed region in 1998-2002.

The total loss in the observed region during the nine-year period (from discarding and safely destroying infected cadavers of slaughtered pigs infected with T. spiralis) was $1022685 \mathrm{~kg}$ and the total value of direct loss, calculated based on mass and market price per $\mathrm{kg}$ of live stock animals was EUR 953012.10 or on average per year EUR 105890.23 . The average annual growth rate of economic damages was $20.3 \%$. Most national authors (Čuperlović et al., 1989; 
Đorđević, 1991; Tešić et al. 2002; Stojiljković, 2005; Mirilović, 2006) list losses arising from discarding cadavers of infected pigs, which have been presented in natural forms - $\mathrm{kg}$ of live stock animals or number of pigs, and rarely expressed as actual value.

Most foreign authors state in their research that infection and contamination of larger or smaller numbers of people were caused by consuming inadequately thermally treated pork meat (Steele and Aranbulo, 1975; Čuperlović et al., 1989). Infected humans, after the incubation period of one to two weeks, develop the acute form of the disease followed by the chronic form (Chodera, 1974; Pawlowski, 1983; Phaheuf et al., 1984; Ramisz, 1989; Čuperlović et al., 1989). There are countries in western Europe (Great Britain, Netherlands and Belgium) which are free from trichinellosis since 1970s (Knapen, 1987). Some countries still have sporadic cases of infection, caused by consuming pork meat or quarry products, which Murrell (1983), Zimmerman (1983), Ramisz (1989) and Pozio (1998) have pointed out in their research. The number of infected and hospitalized males $(58.80 \%)$ in the nine-year period was larger than in female population $(41.20 \%)$, while the highest number of infected people $(64.13 \%)$ was from the 20 59 age group. An indicative fact is that the largest number of infection with trichinellosis has been registered in regional centers and not in smaller inhabited places where the highest prevalence was registered. Namely, since these regions are dominated by a mainly urban population with a higher level of general and health awareness, where it is normal practice to report any changes in health to a doctor, unlike in the rural population, where people consider the disease to be a common cold and do not seek doctor's help. Teodorović et al. (1999) state that the incidence infection of humans with trichinellosis has increased in Serbia in 1990s, the largest number occurring in Vojvodina. The reason being individual slaughter of pigs without veterinary-sanitarian examination. The highest number of infected humans is in the 20-50 age group, which is precisely the age group which can consume the largest quantity of dry-cured and air-dried meat products containing T. spiralis (Stojiljković, 2005; Mirilović, 2006).

Bearing in mind the zoonotic character of the disease, as well as its social significance, the preparation of the program for suppression and eradication of trichinellosis in the observed region is considered justified from both the epidemiological and social points of view. The program covers all activities which have been taken based on positive legal solutions and technical-technological standards of good production practice, as well as the social benefit which is expected from its implementation. The basic activities defined as inputs are: serological diagnostics, rat extermination and trichinoscopies (Table 3). The total expenses for the realization of the program have been anticipated at EUR 3352 650. For the realization of this program, material and work costs for the extermination of rats have been anticipated at EUR 661650 . Having this in mind, it is necessary to ensure a systematic rat extermination, which is pointed out by Teodorović et al. (1999), Tešić et al. (2004), Stojiljković (2005) and Mirilović (2006) in their research. Also, aside from systematic rat extermination, one of the most significant veterinary-sanitarian measures in the control of infection of pigs and eradication of trichinellosis is the trichinoscopic examination of cadavers of 
slaughtered pigs (Kotula, 1983; Zimmerman, 1983; Murrell et al., 1987; Đorđević, 1989; Teodorović et al., 1999), and the prepared program includes the use of such examination in total expenses with $64.68 \%$. Aside from the planned inputs and expenses for their use, we have also predicted a profit of EUR 3871 980. The planned profit based on reducing infection and discarding cadavers of slaughtered pigs and the reduction of expenses of trichinoscopy in the observed territory during the six-year period was achieved by reducing infection of pigs by $30.87 \%$ and saving expenses from trichinoscopies by $69.13 \%$ (Table 3). A similar approach in planning activities for implementing the program of eradication of trichinellosis have been noted in the research of Murrell (1983), Đorđević (1989), Rushton et al. (1999), Teodorović et al. (1999), Knappen (2000), Tešić et al. (2004), Stojiljković (2005) and Mirilović (2006).

The majority of experts, epidemiologists and economists who deal in animal health control management point out that the preparation of a program of animal health control and disease eradication must pay special attention to inputs and outputs and to the expected effect from implementing the program. Since the PNV is negative, and RBC is less than 1, from the economic point of view one can say that the economic justification of the preparation of the program is not expedient. During the six-year period of implementing the program, positive effects have been registered, which are primarily seen in decreasing the incidence of infections in humans in the last two years, as well as in the reduction of prevalence of trichinellosis and the amounts of economic lossess. However, since trichinellosis is a disease of zoonotic character, the economic aspect is not a relevant criterion, unlike the benefits expected from the realization of the program from the health and social point of view, which is the reduction of infections in humans and the prevalence of trichinellosis, which is also pointed out in their research by Carpenter (1994), Thruisfeld (1995), Knappen et Ring (1996), Dijkhuizen et al. (1997), Horst et al. (1999), Tešić et al. (2004) and Mirilović (2006). Therefore, considering these facts and results from other authors, we think that the economic justification of the preparation of the program for the control of trichinellosis in the observed region was sound, which is proved by statistically significant reduction of prevalence $(p<0.01)$ and elimination of infection in humans in the last two years.

Address for correspodence:

Milan Tešić, DVM, MScAE, PhD, Professor

Faculty of Veterinary Medicine

University of Belgrade

Department of Economics and Statictics

Bulevar oslobođenja 18

Belgrade, Serbia

E-mail:mtesic@vet.bg.ac.rs

\section{REFERENCES}

1. Bell RG, 1984, Relationship between site of a primary infection and the expression of rapid expulsion during a challing infection with $T$. spiralis, $6^{\text {th }}$ ICT, Ed. C. Kim, 52-5. 
2. Boireau P, Vallee I, Sofronić Lj, Niborski V, Perrt C, Fabien JF et al., 2002, Natural infected horses with Trichinella spiralis: Topology of muscle larvae, histology and epidemiology. Abstract book ICOPA $X^{\text {th }}$, Vancouver.

3. Carpenter ET, 1993, Animal Health and Production Economics, California, USA.

4. Chodera L,1974, Electrocardiografic changes in acute Trichinellosis, I. observations in human Trichinelosis, Wiad, Parazytologiczne, 1, 113-23.

5. Čuperlović K, Lalić R, Ivanovska D, Sofronić Lj, Bezbradica Lj, Đorđević M et al., 1989, Epizootology and prevalence of swine trichinellosis in an endemic locus in Yugoslavia, Acta Vet (Belgrade), 39, 235-40.

6. Dijkhuizen AA, Huirne RBM, Morris RZ, 1997, Economics decision making in animal health management, in Animal Health Economics, University of Sydney, Sydney.

7. Đorđević $M, 1989$, Raširenost trihineloze svinja u nekim epizootskim područjima SR Srbije i poređenje pouzdanosti nekih direktnih metoda, PhD-Thesis, Faculty of veterinary medicine, Belgrade University, Belgrade, Serbia.

8. Đorđević M, 1991, Detection of Trichinella by various methods in Yugoslavia, Southeast Asiain J Trop Med Pub Health, 22(supp.), 326-8.

9. Horst HS, Vos de CJ, Tomassen FHM, Stelwagen J, 1999, The economics evaluation of control and eradication of epidemic livestock disease, Rev Sci Tech, OIE, 18, 367-79.

10. Knappen van F, 1987, Epidemiological data concerming T. spiralis infection in Netherlands, Wiad, Parazytologiczne, 33, 4-5, 566-8.

11. Knappen van F, Ring C, 1996, European proposal for alternative Trichinella control in domestic pigs, Proseedings 9th ICT, 669-80.

12. Knappen van F, 2000, Control of Trichinellosis by inspection and farm management practices, Vet Parasitol, 93, 385-92.

13. Kotula AW, 1983, Postsloughter control of Trichinella spiralis, Food Technol, 91-4.

14. Murre/l KD, 1983, Preslaughter control of trichinosis, Food Technology, 87-90.

15. Murrell KD, Stringelov F, Dame JB, Leiby DA, Duffy C, Schand GA, 1987, Trichinella spiralis in an agricultural ecosystem, Evidence for natural transmission of Trichinella spiralis from domestic swine to widlife, J Parasitol, 73, 1, 103-9.

16. Mirilović $M, 2006$, Ekonomska analiza epizootiološko-epidemiološkog stanja trihineloze u Srbiji i izrada programa za eradikaciju (Economic analysis of epizotic-epidemiologic status of trishinellosis in Serbia and development of eradication programme). PhD-Thesis, Faculty of veterinary medicine, Belgrade University, Belgrade, Serbia.

17. Pawlowski ZS, 1983, Clinical aspect in man, In Trichinella and Trichinellosis, Ed. W.C. Campbell, Plenum Press, New York. London, 367-401.

18. Phaheuf $D$, Vega $C$, Morisset $R$, Veins $P$, 1984, Trichinosis with cardiac involvment, Proceedings of Sixt ICT, Ed. C. Kim, 114-7.

19. Pozio E, 1998, Trichinellosis in Europian Union: Epidemiology, Ecology, Economic Impact, Parasitol Tod, 14, 35-8.

20. Ramisz A, 1989, Studies on some epizootological and epidemiological problems of Trichinellosis in Poland, CSIC Press, Madrid, Spain, 370-5.

21. Rushton J, Thornton PK, Otte MJ, 1999, Metods of economics impact assessment, Rev Sci Tech, OIE, 18, 315-42.

22. Scripova VL, Zhukovski VE, Hukovski VN, Kovchur NS, 1994, Medicinskaja parasitologya s Parasitarnye bolezni, 2, 22-3.

23. Stojiljković $L j, 2005$, Ekonomski i zdravstveni značaj trihineloze i izrada programa za suzbijanje na epizootiološkom području Požarevac, MSc-Thesis, Faculty of veterinary medicine, Belgrade University, Belgrade, Serbia.

24. Teodorović V, Dakić M, Simić I, Teodorović R, 1999, Trichinellosis, DP "Unifarm" Šabac.

25. Tešić M, Pejin I, Kljajić R, Tajdić N, Mirilović M, 2002, Economics and management in animals health control, In: Katić, V (Ed) Proceedings of the $14^{\text {th }}$ meeting of Veterinariens of Serbia with international participation, Zlatibor, september 10-14, Serbia, 225-34. 
26. Tešić M, Žugić G, Kljajić R, Stojiljković Lj, Rogožarski D, Blagojević M, 2004, Trichinelosis outspread in district area and development of its eradication program, Proceedings $18^{\text {th }}$ IPVS, Vol. 2, Ed. T. G. Blaha et C. Pahlitzseh, Hamburg, june 27 - 1 july, Germany.

27. Thruisfeld M, 1995, Veterinary Epidemiology, Second Edition Blackwell Science, Oxford, England. 28. Zimmerman WJ, 1983, Control II, Surveillance in swine and other animals by muscle examination, Trichinella and Trichinosis, Ed. W. C. Campbell, Plenum Press, New York-London, 515-26.

\section{EFEKTI PRIMENE PROGRAMA KONTROLE TRIHINELOZE NA ENDEMSKOM PODRUČJU U SRBIJI}

TEŠIĆ M, NEDIĆ D, BALTIĆ M, BOŽIĆ DRAGICA, STOJILJKOVIĆ LJ, PLAVŠIĆ B, TAJDIĆ NADA, MIRILOVIĆ M i RAJKOVIĆ M

\section{SADRŽAJ}

Trihineloza je zajedničko oboljenje ljudi i životinja koje izaziva parazit koji pripada familiji Trichinellidae i rodu Trichinella. Čovek se zarazi tako što konzumira zaraženo, nedovoljno termički obrađeno meso domaćih i divljih životinja u kojima se nalazi učaurena infektivna larva $T$. spiralis. Pored zdravstvenih problema koje izaziva trihineloza kao zoonoza, nesumljivo je da ona predstavlja i ozbiljan ekonomski problem za proizvođača svinjskog mesa. Ova istraživanja su izvršena u Srbiji na teritoriji jednog regiona koji se nalazi u slivu dve velike reke, i zbog takvog geografskog položaja predstavlja endemsko područje za prisustvo T. spiralis. Epidemiološki podaci se odnose na period 1995-2003. godine, kao i na period 20032009. godine kada je izvršena implementacija programa kontrole i eradikacije trihineloze. Dijagnostičkim ispitivanjem trupova zaklanih svinja na prisustvo $T$. spiralis u periodu 1995-2003. godina obuhvaćeno je $41.04 \%$ zaklanih svinja od čega je bilo $0.4281 \%$ pozitivnih svinja, a visina ekonomskih gubitaka iznosila je 95301000 dinara ili oko milion EUR-a. U toku posmatranog perioda obolele su 432 osobe. Izrada programa za kontrolu i eradikaciju trihineloze izvršena je na osnovu važećih zakona i tehnoloških standarda, uz jasnu determinaciju „inputa" i „outputa" pomoću „cost-benefit" analize. Efekti njegove primene pokazuju smanjenje broja pozitivnih svinja na prisustvo $T$. spiralis za tri puta $(p<0,01)$, a neto sadašnja vrednost (PNV) i odnos koristi i troškova $(B / C)$ pokazuju ekonomsku i epidemiološku opravdanost. 